\title{
Small EU Initiatives in the Process of Pooling and Sharing of Military Capabilities
}

\section{Zbyšek KORECKI}

\author{
Departmen of Air Force, Faculty of Military Technology, University of Defence, Kounicova 65, 662 \\ 10, Brno, Czech Republic \\ E-mail.: zbysek.korecki@unob.cz
}

\begin{abstract}
The defense budgets of the Member States of the European Union are rising due to the current economic situation and change in the level of security. The goal of approaching two percent of gross domestic product will probably be reached within one decade. However, the positive trend in the development of the defense budget will not allow small states to acquire the exact numbers of military techniques in the numbers that imply a continuous increase the capacity of national armies.

Pooling and sharing is one of the approaches that will allow the required capabilities of national armies to benefit the European Union, or the North Atlantic Alliance. Deepening co-operation in the field of acquisitions will put pressure on coordination of activities, alignment of legislation and, above all, overcoming national and common. Obviously, given the current combat experience, the issue of armed forces has already been partly solved and pooling \& sharing implementation is a political issue.
\end{abstract}

KEY WORDS: pooling \& sharing, smart defence, Visegrád Group, EU battle group, strategic cultures, the clarity of intentions, trust and solidarity, a common acquisition process, common development in defense capabilities

\section{Introduction}

The Pooling \& Sharing project basically relies on activities related to arms and services procurement pooling, joint research background, such as sharing through the partial or full integration of the power structures, the introduction of training facilities or the establishment of joint units; and specialization. There are some practical examples of P \& S in Europe: the France-UK Treaty of November 2010, which is a bilateral agreement on P \& S; the vast experience of the Visegrád Group (Czech Republic, Hungary, Poland and Slovakia) and the Weimar Triangle (France, Germany and Poland). The above-mentioned cooperation examples can be more appropriately labelled as small initiatives for which the P \& S model partially applies. The most important example of the "pooling" of EU Member States' troops is the creation of the capabilities of the EU Battlegroup.

Notwithstanding these initiatives, however, the functioning of the EU P \& S agenda depends on two fundamental factors that have not been fully implemented yet. The first important area is the effective liberalization of the European arms market, which will create more competition among national defence industries, where the necessary condition is the removal of national barriers, and the Europeanisation of a part of the defence budget. The other still missing area is a significant improvement in EU defence cooperation that would lead to the adoption of a concept of reduced diversification level in military equipment and technology in Europe.

\subsection{Method of Investigation}

The methods of scientific knowledge used here based on the need of acquiring data, creating new knowledge, and continuously building on the previous knowledge and contexts of processes. Due to the amount of available book resources, the need for the ability to implement the knowledge gained due to the changes in the implementation of logistical support and the implementation of private and public sector partnership projects on a global scale has emerged. [1] The logical chain of inductive understanding [2] based on the collection of data from different sources in order to find regularity in the data obtained for the preliminary conclusions.

The historical-comparative method is based on the ability to find the same evolution of structures in the commercial sphere and subsequently implement them in the process of the armed forces in the implementation of logistic support at tactical and strategic distances. The dates of involvement of the Armed Forces of the Visegrád Group in the European Union Battlegroups were used. 


\subsection{Investigation Results}

The Visegrád Group states, by taking a decision to create the V4 EU BG, sent a clear signal of their interest in consolidating the EU's position on the international scene [3], and the joint contribution was a practical expression of the support of the Common Foreign and Security Policy.

The creation of a joint V4 formation without the participation of a European "big" player demonstrates the maturity of states [4] and at the same time declares the ability of sub-Central European countries to cooperate within the complex political and military issues that the EU BG is building. State-of-the-art is also supported by the experience gained in previous combat groups together with experienced Union Member States. The positive development of the V4 EU BG was also the ability to offer a position to the Lead State where the Poland republic assumed responsibility for the planning, creation, training and certification of V4 EU BG, while the other participating countries respected PR authority and its responsibility towards the EU. Positive is also the finding of a consensus on the precise distribution of contributions and individual modules so as to eliminate possible shortcomings, particularly in the area of technical or logistical deficiencies [5].

\section{Smart Defense and EU Pooling and Sharing Capacity}

The financial crisis has profoundly affected the European defense budgets and, as a result, the EU's ability to act as a global security provider. It can be said that differences in military spending between EU Member States and lack of coordination are detrimental to EU security cooperation. A possible solution was the acceptance of NATO's intelligent defense alliance, Smart Defense, which uses the processes of sharing and pooling military capabilities. The aim of the new approach is to promote collective capacity building and to balance budgetary constraints.

Thus, in 2011, when Europe was not faced with an imminent threat, the political arguments for increased military spending were not relevant. It is not surprising that states tried to increase efficiency by supporting bilateral or multilateral forms of cooperation with other states.

The NATO Summit in Chicago in May 2012 in its conclusions recommended Member States to reduce costly national programs and seek effective solutions by pooling and sharing resources. Achieving synergy results requires improved understanding of mitigation measures, fulfillment of mandatory requirements by all actors in the distribution chain, and continuous updating of applicable regulations and directives [6]. The P \& S concept is not new, but the new one was a combination of the financial crisis and the lessons learned from the Libyan campaign, which called for a more equitable settlement of the European contribution to NATO's ability to develop a "smart" way to cope with growing defense demands through multilateral cooperation.

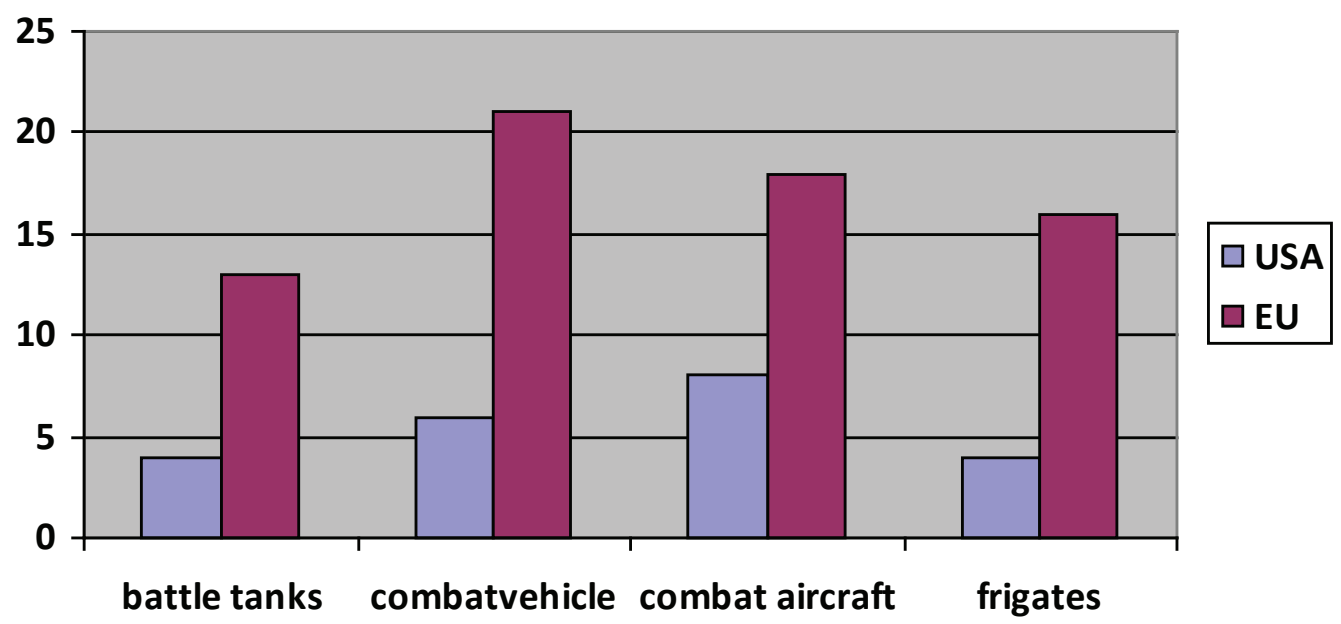

Fig. 1. Different combat platforms between the US and the EU

Implementation of a robust EU P \& S agenda depends on two fundamental factors still needs to be realized. The first is the effective liberalization of the European arms market, which results in greater competition from defense industries that will remove national barriers and the current Europeanization of the defense budget. The second is to achieve a state where national states have diversified military hardware and services that will be able to communicate with each other through technology.

Thus, the critical mass of the EU's defense capabilities is not "big enough" and national capacities are still largely uncoordinated, especially with regard to the acquisition of new technologies. It can also be said that the achievement of the 2010 target on capacity building, based on capacity building, does not reach positive trends and public procurement projects are rather declared as threats to national markets and rivalry. The success of $\mathrm{P} \& \mathrm{~S}$ processes is the EU Battlegroups, 
which represent capacity development, although they have never been deployed, and cannot improve and to innovate mechanisms by creating new capacities.

Economic protectionism and geopolitical aspects could be the answer to clarification the geometry of defense cooperation that prevents defense integration. The result is slow progress in the development of capabilities. The Military Budget therefore represents mandatory spending, 50\%, operating (30\%) and development spending (20\%) [7].

\section{The Process of Pooling and Sharing Capacities}

The unfavorable combination of the financial crisis, which was reflected in the military budgets of the European states, with the already mentioned insufficient military capabilities of the EU, put pressure on the EU around 2010 to seek practical solutions for the elimination of the unfavorable situation.

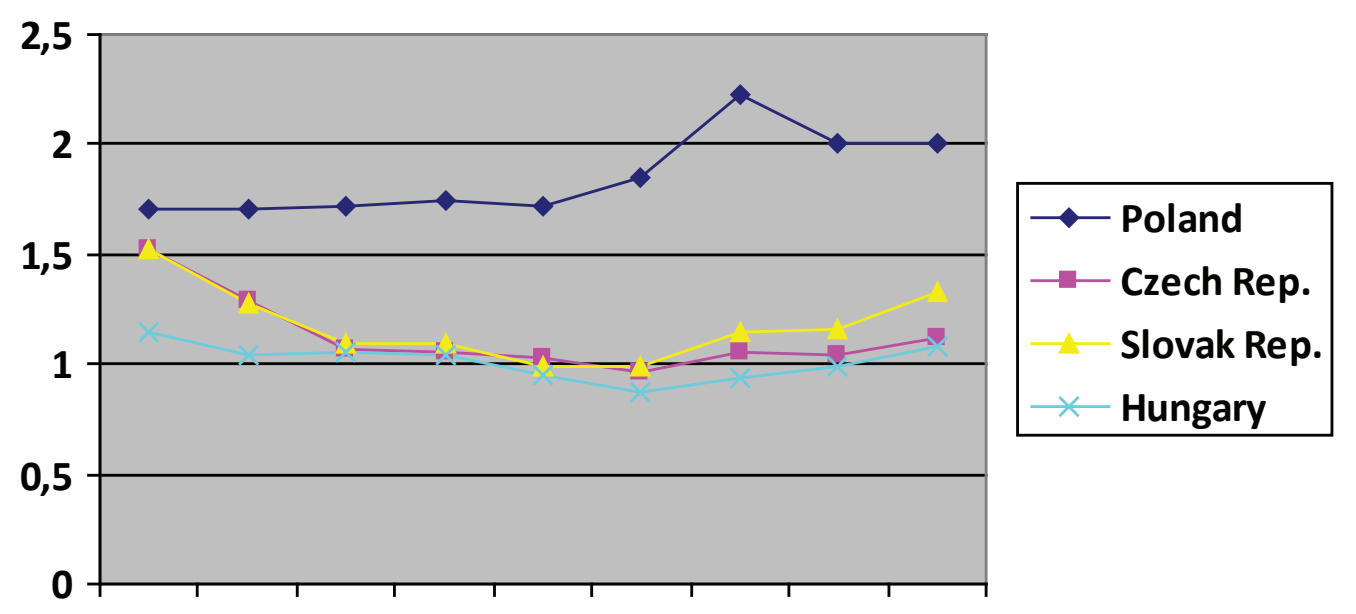

200920102011201220132014201520162017

Fig. 2. Development of the defense budgets of the Visegrád Group states [8]

However, pooling and sharing can currently be defined as an expression of EU security efforts and newly defined threats to eliminate the deficiencies of EU Member States in the area of military capabilities Deep knowledge about the capabilities of their own security systems, environments and relationships between them enables decision makers to make decisions with the least degree of risk [9]. The concept was based on the assumption that the use of P \& S will increase the interoperability of EU Member States' armies. At the same time, the P \& S concept allowed us to identify and eliminate the duplication of military capabilities of European states where national profiling should be reflected in the efficient use of allocated resources. The P \& S concept assumes a wide range of military initiatives, ranging from military education, through joint exercises to participation in the EU BG, to accelerate the process of achieving the required military capabilities [10].

The newly established military cooperation trend was to enable European states to maintain and develop national military operational capabilities and, by implementing $3 \mathrm{E}$, to increase operational capabilities while increasing efficiency, sustainability, interoperability and profitability.

Sharing of Military Capabilities "implemented in the context of multinational defense cooperation is based on the implementation of shared selected military activities within national structures and capabilities of forces, which are not integrated into a single international mechanism. This means that the process of command and control, including control, is the national responsibility of the armed forces. Operational costs are also subject to a breakdown based on the national share of participation. Participating Member States continue to maintain national sovereignty over the control of national forces.

The concept of "pooling", however, in the framework of multinational cooperation, the sharing of military capabilities is a much more complicated and complicated mechanism than a "sharing", given the fact that command and management of shared military capabilities is partly subordinated to national governments, even though defined national capabilities have been integrated into a multinational structure. However, the concept of pooling requires less personnel and operational logistics costs in the process of integrated and coordinated planning.

The most appropriate example of pooling is the construction of multinational safety purpose structures - EU BG or NRF. Multinational command and control structures are established within the purpose of the structures, but participating states retain control over their units, national contributions.

Safety is one of the most important values of every society. If it is not assured of safety, they cannot develop further activities. The national security as a reference object can contribute significantly in various sectors of security and membership in the international community [11]. 
The need to ensure availability has to be based on the "Availability of National Capabilities Agreement" from the very beginning of the implementation of the $\mathrm{P} \& \mathrm{~S}$ processes that require the following activities:

- Analysis of interests and required military capabilities through a consensual solution.

- Identify the range of available military capabilities.

- Performing comparisons of required changes in capacities and structures.

- Substitution of missing competences through a sharing project or so-called "sharing roles".

- Excessive military capabilities that should be phased out in developing national programs due to inefficient development.

- All capabilities should then be analyzed to find out how to use the pooling project and the "sharing role" [12].

Implementation of P \& S projects also raises concerns about the so-called "rejection of shared capacities", which could result in the efforts of one of the participating States being thwarted when other states in a shared unit refuse to grant national contributions to shared capacities. Different national economic strengths can also raise concerns about the fact that economically less advanced states or states with limited national defense capacity will paradise free-riding using the concept of P \& S, exploiting the benefits of cooperation without sufficient reciprocity. [13,14] However, the current form of the P \& S project is, overall, a new direction of mutual cooperation between EU Member States based on a rational approach to solving security dilemmas, while setting the trend to eliminate duplicity, eliminating ineffective military capabilities. The implementation of pooling and sharing projects presupposes a certain level of military cooperation between Member States, based on regional, subregional platform.

\section{Subregional Military and Defense Co-operation}

The concurrent efforts of EU Member States and NATO to find common solutions to defense can result in new and diversified forms of sub-regional, multinational military and defense co-operation reflecting the unfavorable development of financial capabilities and military capabilities. It can be stated that the objective of cooperation of defense-led states is not the interest in creating new structures beyond the existing but above all reduction of operational costs at national level through co-operation and sharing that will allow national states to support the selected military capabilities defined by the White Paper on Defense. [15]

The above described effort corresponds to the P \& S military capability project. A relatively new project does not allow for precise definition of success criteria, but on the basis of experience in defense cooperation, it is possible to identify some factors that allow not only the creation but also the sustainability of security cooperation. The factors identified so far are: geographical proximity, similar geographic size, comparable military power, similar strategic culture, historical political cooperation, and political will of state officials.

In the field of foreign policy criteria, which create the prerequisites for the construction of sub-regional military and defense cooperation between Visegrád countries, it is possible to include:

- Similarity of strategic cultures.

- Trust and solidarity.

- A comparative structure of armed forces and quality in all dimensions.

- Similarity of the defense industry.

- Clarity of intentions. [16]

The signing of the new Visegrád Declaration of May 2004 confirmed the efforts of the V4 states to continue in further cooperation on subregional activities and initiatives to strengthen identity of the Central European region. At the same time, the commitment was confirmed joint co-operation of the Visegrád Group countries in CFSP / ESDP development, strengthening of Euro-Atlantic relations and the relationship between the EU and NATO. The meeting provided another significant incentive to step up mutual cooperation at the sub-regional level in the military-defense area. However, the state declaration of the State representatives did not positively respond to the real development of military cooperation. The reduction in the level of practical military cooperation of V4 countries in the military field, which was only a declaration of a "common platform", lasted from 2004 and took the form of manifestations of the Visegrád group's common positions. Military cooperation between the V4 countries, after accession to the EU and NATO, was largely a political consultation, but it allowed the V4 states to realize a "subregional lobby" in interpreting the Visegrád Group's interests.

The new form of military relations of the V4 states was based on the autonomous behavior of the members and was manifested mainly by the participation of states in many NATO expedition operations, the EU / CSDP and the so-called "coalition of willing". Relationship flexibility was also reflected in the acquisition and upgrading of the national armed forces.

\section{Construction and Readiness of V4 EU BG in 2016}

Operational readiness for deployment of V4 EU BG was from January 1 to June 30, 2016, with post-operative readiness on 1.7. - 30.10. 2016. The formation of the Visegrad countries - Poland, the Czech Republic, Hungary and Slovakia (V4 EU BG) was shared. More than 3,900 soldiers from four countries had a 24-hour emergency room during which they could be sent to resolve a crisis situation anywhere up to six thousand kilometers from Brussels.

In approving the impact of the forces and resources of the V4 EU BG, the V4 parliaments agreed to the force of the 
force for a 6-month standby, but in the future, 120 days from the day of deployment needed to be calculated, requiring a 6 months extension of consent to the force +120 days.

Of the total of over 3900 soldiers of the V4 EU BG. Poland, as the lead country, allocated 1,868 people, the Czech Republic earmarked 728 people, Hungary sent 639 people, and Slovakia sent 466 OS members. Poland has provided a major part of the combat maneuvers for V4 EU BG, Hungary has provided engineers and CIMIC, Slovakia with a Weapons of Mass Destruction UnitWMD. On the V4 EU BG, members of the OS of Ukraine also had to participate in 19 persons.

Poland, as the lead country, declared the creation of the V4 EU BG with operational readiness in the first half of 2016 as early as 19 April 2012 at the EU BG Coordination Meeting in Brussels. Subsequent signed documents, "Cooperation in Developing Capabilities, Solidarity in Sharing Responsibilities" and "Joint Statements of the V4 Ministers of Defense" have enabled the development of joint combat group capabilities in training, and the development of capabilities and their sharing.

The efforts of the V4 countries to harmonize the V4 EU BG Exercise (LIVEX V4 EU BG) with the Trident Juncture Strategic Exercise (TRJE15) proved to be a good solution, and the V4 representatives agreed on the need to link LIVEX V4 EU BG and TRJE15 and, at the same time, V4 territory.

The members of the Army of the Czech Republic were responsible for logistics and health care, where they held the position of the leading country. The Czech Army's logistics ensured the construction of a common ammunition depot, the transport company and the national support element. The Combat Command has established JLSG HQ- Join Logistics Support Group Headquarters for Logistics Coordination. The preparation of the logistics module culminated in the international certification exercise Capable Logistician 2015.

The specialty of preparing the health element was based on the Multinational Medical Modular Approach (Multinational Medical Module Approach). The principle of the principle is based on the use of whole or certain parts of the health modules of the participating states (personnel, infrastructure, and instrumentation) for the creation of a joint medical unit. The ACR's medical staff provided V4 EU BG with the construction of a multinational field hospital (ROLE 2E) on the basis of the 7th field hospital with the active participation of the V4 modules. Capacity testing was carried out by the Medical Man 2015 Certification Exercise.

The armed forces of the Slovak Republic contributed to the V4 EU BG as follows:

- ROLE 1 mechanized company with logistic support for up to 150 people.

- RCHBO Company with its own logistic support unit with a capacity of up to 140 people.

- 12 people, in two teams, for the removal of explosive devices.

- Military Police team of 15 people.

- Movement management team of 10 people.

- ROLE 2 medical team up to 25 people.

- Representatives in the Joint Operations Headquarters for 40 persons.

- Transport company for up to 100 people.

- Intelligence, Survey, and Electronic Combat for 10 people.

- Representatives in teams of psychological operations of 8 people.

- A national support element of 50 people.

- Representatives to the headquarters of a support logistic group of 10 people.

The national certification of the RCHBO module took place in 2015 so that the V4 EU BG certification exercise could take place in the second half of 2015. The Republic of Hungary contributed to V4 EU BG facilities with a ROLE 1 medical collateralized facility with a plurality of logistical support of up to 230 people, units in the CS structure of 127 people, with the structure of the engineer company comprised of 100 people. The contribution to the CSS units reached 75 , the largest part being predestined for the health module in an account of 49 people. The Republic of Poland, which provided 1868 people in total, was represented in all major structures V4 EU BG as follows:

- HQ members of 447 people.

- Mechanized Company, Logistics Company, Command and ROLE 1 Medical Unit, up to 400 people.

- ISR group of 63 people.

- Connecting company up to 65 people.

- Military police platoon up to 40 people.

- Support units, engineer unit, CIMIC and PSYOPS units for up to 130 people.

- JLSG units up to 270 people.

- RSOM process control units up to 460 people.

\section{Conclusions}

From the point of view of the system of management and administration of the V4 Defense Ministry processes, processes of conceptual design must be created. Achieving set goals requires the following processes:

- Set Supply Chains, Define Assigned Resources Using and Processes.

- Set control objectives based on the strategic objectives of defense departments.

- Ensure / create a functional organizational and communication model sharing information to control the objectives of the management and its fulfillment.

- Set up monitoring of goal fulfillment to ensure process management and management is in the planned direction. 
Analyzing the data obtained has led us to conclude that significant variability exists for each material category. This may reinforce the belief that storage management in different displacements achieves low standardization levels and requires the adoption of decisions aimed at centralizing storage management with significant limitation of distribution sites and potential staff cuts while maximizing the use of information technology. Frequency and time consuming inventory inventories are also different depending on the location of the dislocation. The research of the future network and the follow-up logistics services led, among other things, to the development of a versatile packing line facility capable of completing the required types of material, depending on customer requirements. This enables the required material to be completed up to the level of the battalion task force without the need to increase the capacities of the employees.

The establishment of the V4 Planning Group (V4 PG) laid the foundation for more intensive cooperation in the defense planning process. The main task of V4 PG is to seek and propose areas of cooperation with the aim of developing mutual competencies. A prerequisite for the active influence of the V4 PG is the periodicity of meeting when the members of the working group should meet at least twice a year as part of the EU and NATO activities. An important consensus should be the fact that the country pays the costs of the capacities and capabilities it offers.

Due to the requirement to achieve certification of the training units, it would be advisable to set up the number of trainees to a level of up to 1500 people, using the necessary number of support devices and selecting weapon systems according to the scenario of the operation.

It can be predicted that further development of the P \& S project will be implemented in the following areas [17]:

- Common logistics.

- Medical treatment capacities.

- Training in air traffic control.

- Radiation chemical and biological protection.

- Training of helicopter pilots.

- Multinational military experiments.

- Training against improvised explosive devices.

- Joint construction of armored vehicles and ammunition.

- Equipment and armaments of soldiers.

- Integrated command and control systems.

\section{Acknowledgements}

This work was done within the framework of the UoD research project "Support for ACR Aviation Activities in Local Conflicts “.

\section{References}

1. Manglig, F. Aplikační možnosti moderních simulačních systémů. [Habilitační práce], TU v Liberci, KVS.

2. Manglig, F., Keller, P. Možnosti využití počítačové simulace. In: Automatizácia technologickej prípravy výroby. Odborný seminár s medzinárodnou účastou, Zvolen 17.09.1998, Zborník prednášok.

3. Korecki, Z., et al. Distribuce humanitární pomoci a udržitelnost subjektů v humanitární operaci, 1.ed. Ostrava: Key publishing s.r.o., 2015.

4. Korecki, Z., et al. Military Logistics during Operations on African Territory under the EU Flag. 1.ed. Ústí nad Labem, Střekov: Private Autonomy, 2010.

5. Korecki, Z., Cabicarová, M. Logistika v humanitární operaci. 1.ed. Brno: Univerzita obrany, 2014.

6. Korecki, Z., Adámková, B. Implement policies and processes to increase the level of security of the multi-tier logistics chain. In. New Trends in Aviation Development 2018. [online]. Available from: http://www.ntad.lf.tuke. sk/ s. 76-81. ISBN: 978-1-5386-7917-3.

7. Brizgalová, L., Vránová Z. Economic security from point of view of raw material sufficiency and defence force. In. Economics and management, 2016, no. 1/2016, s. 7-17. ISSN 1802-3975.

8. SIPRI Military Expenditure Database. [online cit.: 2018-03-23]. Available from: https://www.sipri.org/databases/ milex.

9. Dukiewicz T. Security and information in the military environment. In: Security Forum 2014 (1): s. 97-109. Zbornik vedeckých prác [dokument elektroniczny], red. Ušiak, J., Lasicová, J., Kollár, D. ISBN 978-80-557-0677-1.

10. Adámková, B., Fukala, M. Security consequences of development in Georgia in the year 19991 - 2015 with impact on economic development. In: Security forum 2017: s. 6-19. Banská Bystrica, Slovakia: Interpolis, 2017. ISBN 978-80-972673-2-2.

11. Čičmanec L., Nevrlý, J. Capabilities and Applications of Fuzzy Logic in Airport Operations. In: ICMT’12 International Conference on Military Technologies 2012: s. 382-386. Bratislava: Alexander Dubek University of Trenín, 2012. ISBN 978-80-8075-525-6.

12. Overhage, T. Less is More: Pooling and Sharing of European Military Capabilities in the Past and Present, Naval Postgraduate School, Monterey, Master's Thesis, California USA, June 2012. s. 29. [online cit.: 2016-01-28]. Available 
from: http://www.dtic.mil/dtic/tr/fulltext/u2/a563507.pdf.

13. Valášek, T. Surviving austerity: the case for a new approach to EU military, London: Centre for European Reform, 2011, s. $20-21$.

14. Möckli, D. Smart Pooling: State of Play in European Defence and Armaments Cooperation, CSS Analysis in Security Policy, No. 126, Zurich, December 2012. s. 1. [online cit.: 2016-01-23]. Available from: http://www.css.ethz.ch/ publications/pdfs/CSS Analysis-126-EN.pdf.

15. Ivančík, R., Nečas, P., Jurčák, V. Theoretical view of some current global security challenges. In: Incas Bulletin, 6(1), 2014, s. 99-107. ISSN 2066-8201.

16. Valášek, T. Surviving austerity: the case for a new approach to EU military, London, Centre for European Reform, 2011, s. $21-24$.

17. Školník, M., Belan, L. Obranné plánovanie - Základy plánovania a projektovania v systéme obrany a bezpečnosti SR. Akadémia ozbrojených síl GMRŠ v Liptovskom Mikuláši, 2015. University textbook, 189 s. ISBN 978-80-8040-522-9. 